\title{
The "Custrac Model": Its Generic Practicality with a Twist in the Ghanaian Education
}

\author{
Samuel Affran ${ }^{1 \& 2}$, E. N. Gyamfi ${ }^{1 \& 3} \&$ S. Odonkor ${ }^{1 \& 3}$ \\ ${ }^{1}$ Livingstone International University of Tourism Excellence \& Business Management, Zambia \\ ${ }^{2}$ Department of Marketing, Procurement and Supply Chain Management, Winneba \\ ${ }^{3}$ Ghana Institute of Management and Public Administration, Accra, Ghana \\ Correspondence: Samuel Affran, Department of Marketing, Procurement and Supply Chain Management, \\ Winneba, Livingstone International University of Tourism Excellence \& Business Management, Zambia. E-mail: \\ saffran@uew.edu.gh
}

Received: September 3, $2021 \quad$ Accepted: October 14, $2021 \quad$ Online Published: November 15, 2021

doi:10.5539/ijms.v13n4p42 URL: https://doi.org/10.5539/ijms.v13n4p42

\begin{abstract}
The purpose of the study is to promulgate the "custrac model" that proposes how the Ghanaian university management through its relationship officers can attract fully qualified and competent students globally. Following a survey technique, data were collected from 500 respondents from the top five Universities in Ghana. Analysis was done using SmartPLS 3 to perform partial least square regression analysis on the structural equation model. Findings revealed that customer attraction is constructed on loyalty and further enhanced by satisfaction. The study focused on few respondents from only five public universities in Ghana, thus, inhibiting the generalization of the findings. Practically, the "custrac model" suggests that the university management should align their strategic relationship marketing stratagems in developing competitive and market-driven programs having in place a strong quality assurance directorate to attain customer attraction. The proposed "Custrac model" in this study shoots up our intellectual understanding of strategic relationship marketing.
\end{abstract}

Keywords: "Custrac model”, strategic relationship marketing, SmartPLS3, Ghana, universities

\section{Introduction}

Most Ghanaian universities are confronted with the issue of attracting fully qualified and competent students (Gyamera et al., 2021; Kwegyiriba \& Mensah, 2021). The issues are quite the same in other parts of Africa (Rotberg, 2020). Higher institutions in this part of the world are finding it very difficult to entice students (Calhoun et al., 2021) to pursue academic programs of their choice (Kuranchie et al., 2021). Empirically research shows that about $75 \%$ of students are fascinated and tend to attend university with the state of art facilities (Gbadegesin et al., 2021) provided. Physical infrastructure (Eberle et al., 2021) is also viewed as an attractive force most often than not. Building an active website (Otto et al., 2021) with swift institutional information delivery (Swift, 2021) tends to attract a good caliber of students. The strength of the faculty (Bowker, 2021) cannot be left out as it serves as a conduit for attracting students. Statistically, the evidence further shows that student enrolment keeps on tumbling by $2 \%$ each academic year (Uriegas et al., 2021) notwithstanding the effort made by the university management. Prominent among these causes is that: first, most of the universities are bankrupt when it comes to relationship construction with their current and prospective students (Dixon et al., 2021). Second, most programs run are contemporary, not relevant. Third, facilities or edifices are not student-friendly (Classens et al., 2021) in some of the universities. Structures are put up without bearing in mind the students' coziness (Shaikh, 2020). They think only about the university and just to make the environment beautiful (Cage \& Howes, 2020). The university management has forgotten that a (Balinado et al., 2021) good product or service cannot sell unless it meets customer satisfaction. In this case, the student's needs and wants should be the focal point when designing an academic program within the parameters of the university (Gupta, 2021). The students' needs should be and must be a top priority of the university (Lee, Jeong, \& Cho, 2021) in order not to pave a way for any form of dissonance. It's upon this note that the researcher has taken the trouble upon himself to promulgate the "custrac model" underpinned by the cognitive dissonance theory that tries to suggest how the university management through its relationship officers can attract fully qualified and competent students on the bedrock of satisfaction. 
To achieve this height structural examination was conducted to ascertain the indirect mediating relationship that exists between relationship marketing stratagems, student satisfaction, and student loyalty disposition. The study was subsequently guided by this research question: How do student satisfaction indirectly mediate the relationship between strategic relationship marketing stratagems and student loyalty disposition? The conceptualization of "custrac" model contributes to the relationship marketing literature. This work also responds to the current academic discourse on (Ali \& Anwar, 2021) the need for researchers to investigate the strategic intent of relationship building on institutional student attraction. To end with, the research findings are tailed with discussions and implications for theory, practice, and recommendations for future research.

\subsection{Literature Review}

\subsubsection{Theoretical Background and Hypothesis Development}

This study is reinforced by "cognitive dissonance theory" which "assumes that individuals continuously strive to maintain a balanced cognitive system." Thus, the priority of every consumer is to minimize the under hidden discord after the purchase and consumption of a good or service. Concerning this study, the theory seems to suggest that students tend to strike a cognitive balance to attain institutional satisfaction before they could be attracted to any university of their choice. It is therefore likely for the student to remain attracted to such a university if the satisfaction rate is quite high after the consumption of the institutional service delivery. In a situation where the student is dissatisfied with the services, it will become impossible to remain loyal to the university. If the cognitive dissonance, along with its switching intentions decreases in the course of a business relationship, then an explanation as to why long-term business relationships develop can be provided by the cognitive dissonance theory. We would like to reiterate that this theory, presupposes that strategic relationship marketing stratagems used in this study should exhibit these potentials of creating satisfaction thus reducing dissonance in the mind of the students. Effectively, it should possess the ingredients to attract fully qualified and competent students consistently. These stratagems should be in the position to elicit positive responses on what the university management has to do to achieve the research objective. These strategic resources should provide the foundation to develop the university's capabilities that can lead to superior performance over time. This study capitalizes on the rulebooks of cognitive dissonance theory to further our understanding of strategic relationship marketing stratagems on how to attract students in the context of Ghanaian education. A critical look at some of the scholarly works revealed that certain dimensions of institution service quality can equally be viewed as strategic relationship marketing stratagems (Zahia et al., 2021) thus having the ability to attract students thus reducing dissonance, but it's (Kirimi, 2021) sustainability remains questionable. Some scholars share the opinion that accessibility in terms of the ease of contact and the approachability of university management (Brown, 2021) to a large extent can be used to attract more students. Buchs et al. (2021) also argued that the scholarly competence displayed by the university tends to enhance some cognitive soundness thus attracting more students. Assurances by the university workers to the entire student body could also resolve some imbalances which help achieve the students' expectations (Scharoun \& Muratovski, 2021). An appeal was made by (Nyakurerwa, 2021) that personnel of the university should show courtesy to their clientele at any given moment. Supported by (Kenfack \& Öztüren, 2021) politeness and respect by the university staff are key ingredients to institutional attractiveness thus boosting the confidence for the students to remain loyal to the university. Considerations and friendliness of frontline workers (Haigler, 2021) are also critical in drawing prospective students. Other scholars are of the view that the communication platform is of great importance (Akova \& Kantar, 2021; Decuypere \& Landri, 2021; Ewing, 2021; Durnen, 2021).

Other literature (Ahakwa, Yang, Tackie, \& Bankole, 2021) suggests that the university should adopt a media channel that is multi-versatile reaching diverse target audiences concomitantly. Credibility on the part of university management is viewed to be crucial for top quality services in the higher education setup (Tight, 2021) whereas reliability (Alshurideh et al., 2021) cannot be compromised in every given space. Davids (2021) posits that responsiveness is a nonnegotiable instrument when it comes to student institutional preference, whereas employee's knowledge and gallantry, and aptitude to inspire confidence are imperative (Shuh, 2021) when it comes to student guarantee in the university setting; factors such as tangibles (appearance of physical facilities, equipment, personnel, and communication materials) and security are of great importance for attracting prospective students (Camilleri, 2021). Pflüger (2021) postulates that understanding the students' needs and wants can position the university competitively and reduce cognitive dissatisfaction. It is therefore critical to note but yet to be conceptualized (Fitzpatrick, 2021) in the higher education sector. Aesthetically, the general look of the university environment, its public image (Steimer, 2021) perceptually energizes the students' predilection while conformance and international standardization ( $\mathrm{Li}$ et al., 2021) is a prelude by which students accept a university as a choice for study. Budur et al. (2021) viewed sacrificial behavioral tendencies exhibited by the university 
workers reduce academic stress, improving satisfaction, and reducing dissonance thus very vital for attracting students. Shahzad et al. (2021) posit that professional skills have a direct positive relationship with university service quality. Reputation and credibility were argued by Kazemian et al. (2021) as an antecedent of educational service quality. Khan et al. (2021) also concluded that the concept of satisfaction remains very imperative for practitioners and academic researchers in the educational sector. A Series of attempts have been made by scholars (Hopkins, 2021; Smart, 2021) to quantify and expound institutional satisfaction, yet there appears to be less harmony (Vargas-Hernández et al., 2021) regarding its designation from the educational perspective. It is seen as a post-purchase behavior (Marques et al., 2021) for evaluating an individual judgment concerning a specific service. Alam et al. (2021) argued its importance to institution service delivery. Carlisle et al. (2021) are also of the view that the future needs of the students are shaped by their current expectations. It is found that student satisfaction has a direct positive relationship with the choice of institution (Budiyanto et al., 2021) and that the individual satisfaction level is deferential between expected and perceived performance. Other Studies (Fook et al., 2021; Javed, 2021) show that the ambiance of the institution may have an indirect impact on student satisfaction. Cus et al. (2021) argued from a different perspective that faculty strength and the managerial philosophy adopted by university management positively affect student satisfaction. Hilda et al. (2021) found out that security, value for money, and courtesy of university staff define student satisfaction while Diaz et al. (2021) discovered that convenience of location, prompt service, safety, and security, and friendliness of employees of the university are critically important. Buabeng-Andoh (2021) specified that employee attitude is likely to influence students' satisfaction. Customer satisfaction is proven to be an empirical outcome of relationship marketing in the service industry but (Buabeng-Andoh, 2021) is yet to be ascertained in the higher education context. Imperatively, the customers are superior to any other thing and their satisfaction is paramount. Ali et al. (2021) stated that it is an assessment of alteration between prior expectations about the product and its actual performance. Boateng et al. (2021) also concluded that is how clienteles respond to the state of gratification, and magistrate the satisfaction level. Gbadegesin et al. (2021) also viewed it as a reaction of the student toward a state of the nirvana and decision of the student about that fulfilled state. Christian et al. (2021) also viewed it as the anticipation before patronizing a product or service concerning quality. Chen et al. (2021) it is a pre-consumption verdict or hopes while Yapanto et al. (2021) opinioned it to be a result of the acquisition in which students relate to cost and rewards with the foretold significances. Based on these reviews the "custrac model" is projected and hypothesized below:

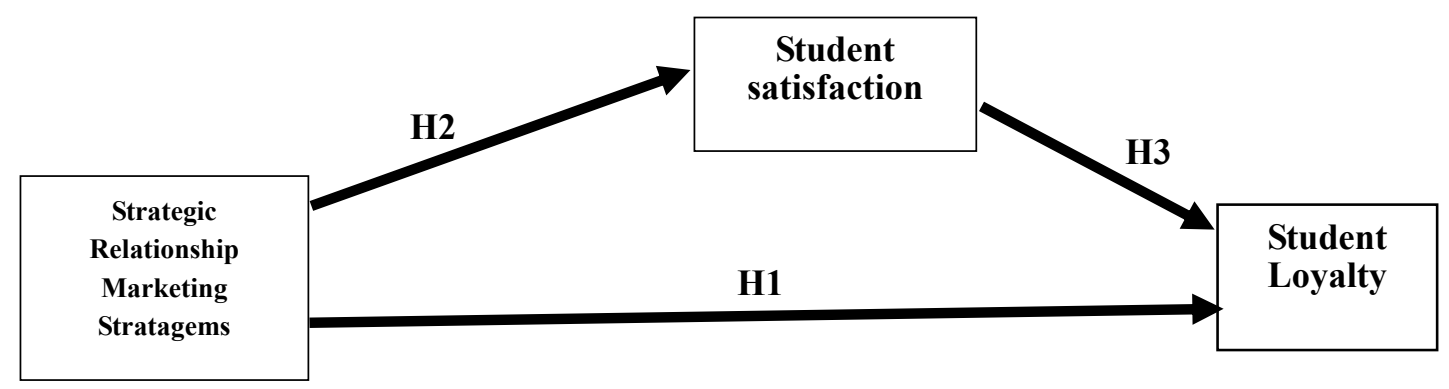

Figure 1. The proposed "Custrac model"

The "Custrac Model" is based on the assumption that customer (student) attraction is constructed on loyalty and further enhanced by satisfaction.

H1: SRM stratagems have a direct positive relationship with student loyalty.

H2: Student satisfaction has an indirect positive inclination on student loyalty and the institution's SRM stratagems.

\section{Research Method}

Premised on the quantitative approach the study is purposed to develop a model that suggests how the Ghanaian university management through its relationship officers can attract fully qualified and competent students consistently. Structure examination was carried to ascertain the mediating effect of student satisfaction on strategic relationship marketing stratagems and student loyalty disposition. Descriptive and hypothesis testing was used to untangle research questions Zina (2021). The research strategy was a cross-sectional survey using a close-ended questionnaire as the instrument. The questionnaire was structured as follows: Section A of the research instrument collects demographic information such as gender, status, name of institution, years of 
working in the university. Section B of the questionnaire draws data about the strategic relationship marketing stratagems through a five-level Likert scale within which number 1 indicates strongly disagree and number 5 indicates strongly agree. The last section collected data on strategic relationship marketing outcomes (student satisfaction and student loyalty disposition. Analysis was done using SmartPLS 3 to perform partial least square regression analysis on the structural equation model of the purpose of the study. The findings were used to formulate the "custrac model."

\section{Results and Discussion}

The research proposed the "Custrac" model, where "custrac" means "customer attraction". It is based on the assumption that customer (student) attraction is constructed on loyalty and further enhanced by satisfaction. Practically, management in all spheres of businesses should concentrate its strategies on achieving satisfaction and loyalty concomitantly. Contextualizing it in the Ghanaian education sector, it postulates that the Ghanaian university management through its relationship officers can attract fully qualified and competent students through a conscious loyalty scheme further enhanced by satisfaction packages. Subjectively, exponents of this model think that students are attracted to universities that satisfy their needs promptly and appropriately. This means that the entire strategic relationships marketing stratagems that university management deploy through its relationship officers should be driven towards addressing students' needs and wants. Consequentially, the attraction rate will escalate when students' expectations are exceeded. Drawing inspiration from the analysis it could be seen that $11 \%$ of the changes in student loyalty disposition can be attributed to changes in strategic relationship marketing stratagem (SRMS) and student satisfaction. The results further show that a unit change in SRMS will reduce student loyalty disposition by $6.7 \%$, which means that as SRMS increases, students' loyalty decreases. Thus, the relationship is inverse. However, student satisfaction mediates positively on the connexion between SRMS and student loyalty, $7.7 \%$ of changes in student satisfaction can be attributed to changes in SRMS, and a unit change in SRMS will cause a $27.8 \%$ change in student satisfaction while a unit change in student satisfaction will cause a $34.4 \%$ change in student loyalty outlook. It implies that the indirect link of student satisfaction is very important in increasing student loyalty. The model for the analysis is impressed by the linear equation $\mathrm{CL}=0.11$ - SRMS (0.06) $+0.344(\mathrm{CS})$ Equation 1: Model $1 \mathrm{CS}=0.077+0.24(\mathrm{SRMS}) \ldots$ Equation 2: Model $2 \mathrm{CL}=0.11-\operatorname{SRMS}(0.06)+0.344(0.077+0.24(\mathrm{SRMS})) \mathrm{CL}=0.11-\mathrm{SRMS}(0.06)+$ $0.026488+0.08256(\mathrm{SRMS}) \mathrm{CL}=0.136488-0.06(\mathrm{SRMS})+0.08256(\mathrm{SRMS}) \mathrm{CL}=0.136488+0.02256$ (SRMS)... Equation 3: The Regression Model. The results in equation 4 indicate that student satisfaction is very important for creating a positive relationship between strategic relationship marketing stratagem and student loyalty. The regression model explains that in the situation where there are no changes in the university's SRMS, student loyalty will increase by 0.136488 or approximately $13.6 \%$. However, a unit change in SRMS will cause a 0.02256 or approximately $2.3 \%$ change in student loyalty if only student satisfaction (competitive market-driven course and vibrant quality assurance directorate) are instituted by the university. The "custrac model" is shown in Figure 2. 


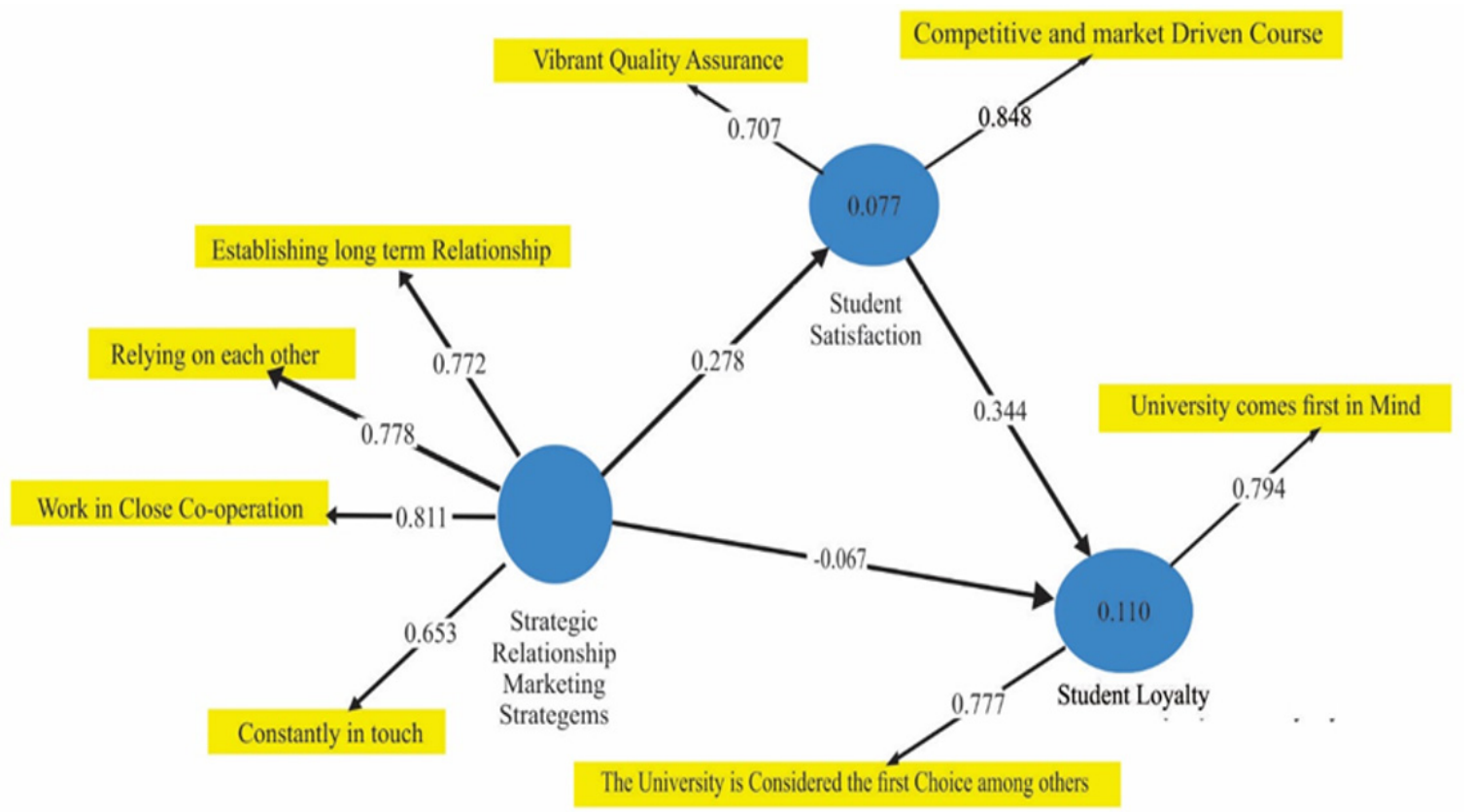

Figure 2. The "custrac model" as per the result which rightly affirms the proposed model

\subsection{The Quality Criteria of the "Custrac Model"}

Specific elements were selected, tested, and measured in the analysis to affirm the quality of the model. The Cronbach's Alpha and Composite Reliability are both measures of reliability; however, the Cronbach's Alpha indicates the reliability of each construct in isolation while the Composite Reliability indicates the reliability of the construct as part of the model as a whole. It can be observed that student loyalty (0.379) and student satisfaction (0.367) are not very reliable as they are standalone but as part of the model, they have very high reliability $(0.763 \& 0.756)$ respectively. On the contrary, strategic relationship marketing stratagems are very reliable both in isolation and as part of the model $(0.754 \& 0.841)$ respectively. Similarly, the rho_A values $(0.380,0.385 \& 0.779)$ respectively in table1 being less than 1 means that the factor model in Figure 2 is valid. If further implies that each construct is significantly explained by its factors. Also, since the AVE values $(0.617$, $0.609 \& 0.571$ ) respectively are greater than 0.5 , means that for each of the three constructs, the factors correlate positively with each other in the construct. Therefore, the respective four factors of strategic relationship marketing stratagem, the two factors of student satisfaction, and the two factors of student loyalty do not linearly predict each other.

Table 1. Reliability and validity of the "Custrac Model"

\begin{tabular}{lllll}
\hline & Cronbach's Alpha & rho_A & $\begin{array}{l}\text { Composite } \\
\text { Reliability }\end{array}$ & $\begin{array}{l}\text { Average Variance } \\
\text { Extracted (AVE) }\end{array}$ \\
\hline student Loyalty & 0.379 & 0.380 & 0.763 & 0.617 \\
student Satisfaction & 0.367 & 0.385 & 0.756 & 0.609 \\
Strategic Relationship Marketing Stratagems & 0.754 & 0.779 & 0.841 & 0.571 \\
\hline
\end{tabular}

\subsection{Discriminant Validity}

This is to test whether underlying constructs are related or unrelated. The Fornell-Larcker Criterion in Table 2 shows that student Satisfaction and Strategic Relationship Marketing Stratagems varied significantly from student loyalty. This confirms the values AVE and composite reliability which shows that the factors influencing the constructs do not linearly predict each other and its construct had high reliability. Also, the f-square values indicate that student satisfaction and Strategic Relationship Marketing Stratagems are very important for ensuring student loyalty. Finally, the HTMT being less than 0.9 indicates there is a true correlation between student loyalty, student satisfaction, and Strategic Relationship Marketing Stratagems. In conclusion, the three constructs are unrelated hence the model is good for policy and resource allocation 
Table 2. Test of Independence of the constructs in the "Custrac Model"

\begin{tabular}{|c|c|c|c|c|}
\hline Measurement & Constructs & student Loyalty & student Satisfaction & $\begin{array}{l}\text { Strategic Relationship } \\
\text { Marketing Stratagems }\end{array}$ \\
\hline Fornell-Larcker & Student Loyalty & 0.786 & & \\
\hline \multirow[t]{2}{*}{ Criterion } & Student Satisfaction & 0.325 & 0.781 & \\
\hline & $\begin{array}{l}\text { StrategicRelationship Marketing } \\
\text { Stratagems }\end{array}$ & 0.029 & 0.278 & 0.756 \\
\hline \multirow[t]{3}{*}{ F-Square } & Student Loyalty & & & \\
\hline & Student Satisfaction & 0.123 & & \\
\hline & $\begin{array}{l}\text { Strategic Relationship Marketing } \\
\text { Stratagems }\end{array}$ & 0.005 & 0.08 & \\
\hline Heterotrait-Monotrait & Student Loyalty & & & \\
\hline \multirow{2}{*}{ Ratio (HTMT) } & Student Satisfaction & 0.855 & & \\
\hline & $\begin{array}{l}\text { Strategic Relationship Marketing } \\
\text { Stratagems }\end{array}$ & 0.117 & 0.504 & \\
\hline
\end{tabular}

\subsection{Significance of the "Custrac Model" and Hypothesis testing}

The results in Figure 3 are the t-value that measures the size of the difference relative to the variation in the sample data. The t-value is the calculated difference represented in units of standard error hence the greater the magnitude of $t$, the greater the evidence against the null hypothesis. The t-statistic determines the significance of the relationships in the model because it measures how many standard errors the coefficient is away from zero. Generally, any t-value greater than +2 or less than -2 is acceptable. However, the higher the $t$-value $>=2$ implies the relationship is significant. It can be observed in Figure 3 that all the relationships between the constructs and the factors influencing each construct have t-values greater than 2 . This implies that both null hypotheses are rejected and the alternative accepted. Therefore, there is a significant relationship between student loyalty and strategic relationship marketing stratagem. Also, student satisfaction significantly influences the relationship between student loyalty and strategic relationship marketing stratagem.

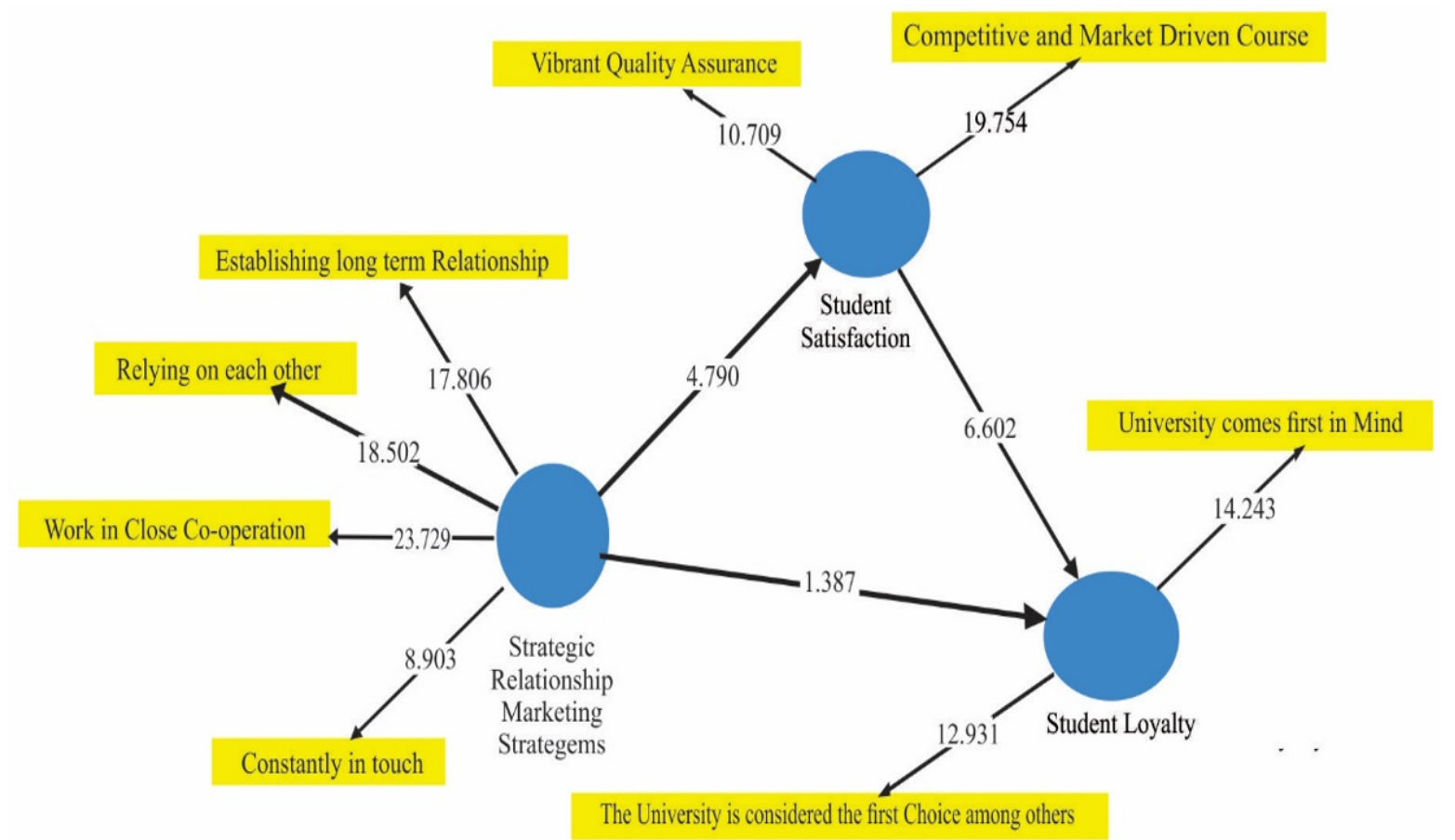

Figure 3. The Significance of the "Custrac Model"

\subsection{Predictiveness of the "Custrac Model"}

It can be observed from Figure 4 that student satisfaction and strategic relationship stratagems can predict 5.8\% 
of student loyalty while strategic relationship marketing stratagems also predict $4 \%$ of student satisfaction. It suffices to conclude that customer satisfaction is very important for improving student loyalty due to its strong link with strategic relationship marketing stratagems.

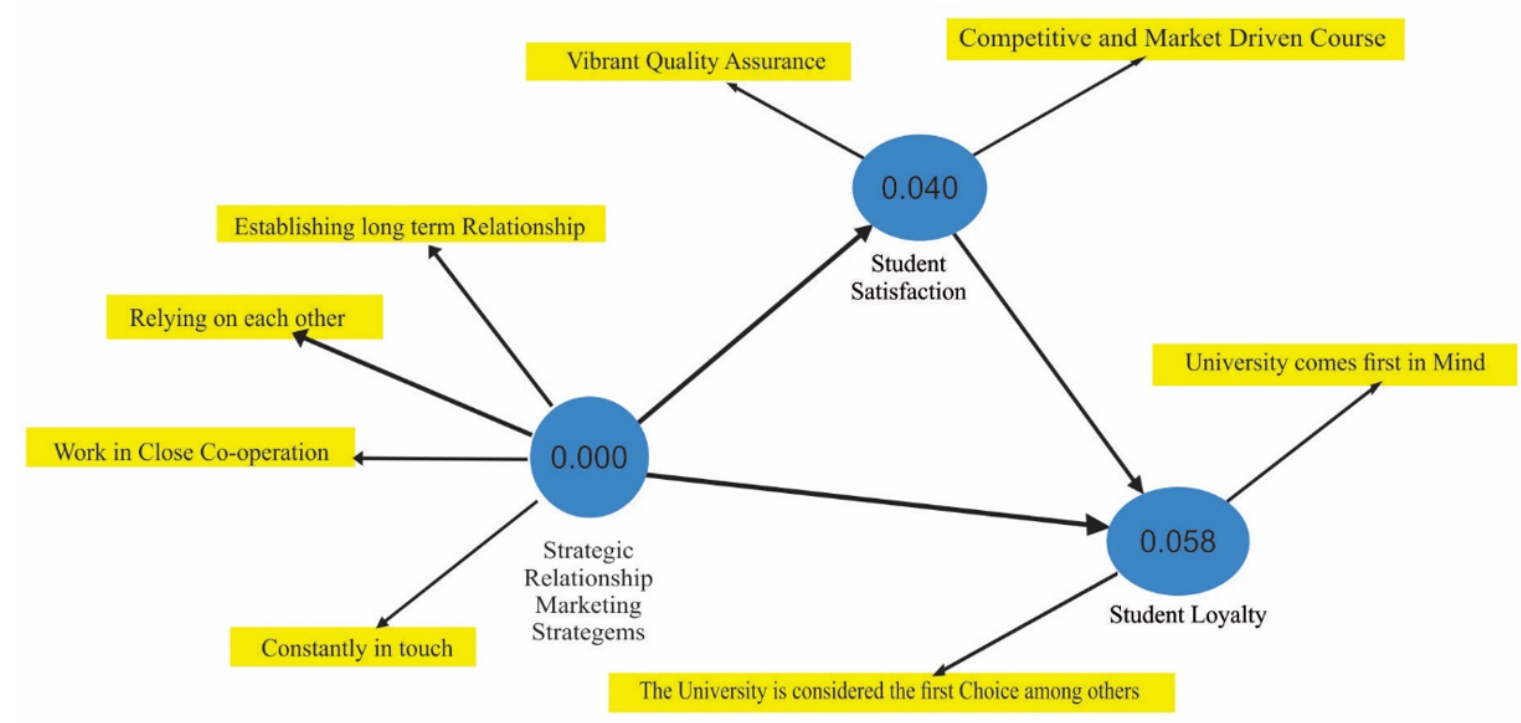

Figure 4. Predictiveness of the "Custrac Model"

\section{Conclusion}

The following marketing implications can be inferred from the analysis; it can be observed from the "Custac Model" that among the empirically adopted strategic relationship marketing stratagems (trust, competence, communication, service excellence, conflict handling, commitment, and bonding) statistically, bonding and service excellence variables were determined significant for the "custrac model." Thus, university management through its relationship officers may adopt these strategic relationship marketing stratagems of building strong institutional bonding with its students by establishing long term relationships $(0.772)$, relying on each other $0.778)$, working in close cooperation (.0811), keeping in touch constantly $(0.653)$ which are consistent with (Nisar et al., 2021; Laplume et al., 2021) but strongly disagreed by (Naudé \& Nagler, 2021). Having these stratagems in place may not necessarily capture the potential students because it is shown that they may have an inverse relationship with the student loyalty disposition (Naudé \& Nagler, 2021). Meaning it did not guarantee that students will have the university in mind as their preferred choice (Tariq et al., 2021). The practical implication is that sheer bonding (Affran et al., 2019; Affran, 2019) strategies employed by the university management tend to lose their efficacy (Liu, 2021) when they are known by the student body. Thus, the supposed decreasing effect of student loyalty disposition is as a result of the students being aware of the institutional bonding strategies meted to attract them. The point is that these strategies are to be kept secret on the blind side of the students (Raciti, 2021). It loses its potency (Ndichu et al., 2021) as soon as they get to know. Per the "custrac model" the university management has to position these stratagems on achieving service excellence that responds to student needs by introducing (Cox, 2021) competitive and market-driven courses (0.848), coupled with (Suleiman et al., 2021) a vibrant quality assurance directorate (0.707) for persistence and continuous monitoring. The "custrac model" has therefore affirmed the notion that students can be attracted to the university (Fraser \& Mancl, 2021; Nurmukhanova et al., 2021) when the university has in place competitive and market-driven courses: 0.848 ) The advice is that: management should establish long term relationship with the students, management should consider and involve students in long term strategic decision, management should work closely with the student body during the implementation of long term strategic decision and management should constantly get in touch with students both current and past during policy formulation and evaluation. However, introducing competitive and market-driven programs driven with a vibrant quality assurance directorate were considered to be the more effective means of attracting fully qualified and competent students consistently. Therefore, for policy formulation and resource allocation, the university management needs to dedicate resources to step up the quality assurance directorate and also introduce more competitive and 
market-driven courses if it has any intention of attracting fully qualified and competent students. Confined only in Ghana, researchers can explore further the concept of strategic relationship marketing and come out with a workable framework. The model can also be tested in other business jurisdictions.

\section{References}

Affran, S. (2019). Scholastic Assessment of Insurance Productiveness from the Marketing Perspective. European Journal of Business and Management Research, 4(6). https://doi.org/10.24018/ejbmr.2019.4.6.95

Affran, S., Mawuko, D., \& Oduro, R. (2019). Relationship Marketing: A Strategic Tool for Sustainable Competitive Advantage. GIS Business, 14(3), 54-65. https://doi.org/10.26643/gis.v14i3.1969

Ahakwa, I., Yang, J., Tackie, E. A., \& Bankole, K. (2021). Exploring the Impact of Traditional Communication Channels on Customer Purchase Decision: A Case Study of University Students in Ghana. Seisense Business Review, 1(1), 31-44. https://doi.org/10.33215/sbr.v1i1.561

Akova, S., \& Kantar, G. (2021). Effects of voluntary activities of university students on reputation management strategies of universities: Sample of public university. Journal of Public Affairs, 21(1), e2149. https://doi.org/10.1002/pa.2149

Alam, S. S., Ali, M. H., Omar, N. A., \& Hussain, W. M. H. W. (2021). Customer satisfaction in online shopping in growing markets: An empirical study. In Research Anthology on E-Commerce Adoption, Models, and Applications for Modern Business (pp. 1878-1892). IGI Global. https://doi.org/10.4018/978-1-7998-8957-1.ch093

Ali, B. J., \& Anwar, G. (2021). Marketing Strategy: Pricing strategies and its influence on consumer purchasing decision. International Journal of Rural Development, Environment and Health Research, 5(2), 26-39. https://doi.org/10.22161/ijreh.5.2.4

Alshurideh, M. T., Kurdi, B. A., AlHamad, A. Q., Salloum, S. A., Alkurdi, S., Dehghan, A., ... Masa'deh, R. E. (2021, June). Factors affecting the use of smart mobile examination platforms by universities' postgraduate students during the COVID 19 pandemic: An empirical study. Informatics, 8(2), 32. Multidisciplinary Digital Publishing Institute. https://doi.org/10.3390/informatics8020032a

Balinado, J. R., Prasetyo, Y. T., Young, M. N., Persada, S. F., Miraja, B. A., \& Perwira Redi, A. A. N. (2021). The Effect of Service Quality on Customer Satisfaction in an Automotive After-Sales Service. Journal of Open Innovation: Technology, Market, and Complexity, 7(2), 116. https://doi.org/10.3390/joitmc7020116

Barney, J. B. (2021). The Emergence of Resource-Based Theory: A Personal Journey. Journal of Management, 47(7), 1663-1676. https://doi.org/10.1177/01492063211015272

Boateng, S., \& Asinyo, B. K. (2021). Exploration of textile art as a medium against corruption in Ghana. Doctoral dissertation.

Bowker, L. (2021). Exploring Faculty Perspectives on College-to-University Transfer in a Large Canadian University. Community College Journal of Research and Practice, 45(4), 290-306. https://doi.org/10.1080/10668926.2019.1703845

Brown, M. (2021). Learner-Centred Education and Adult Education for Migrants in Malta. In Learner-Centred Education for Adult Migrants in Europe (pp. 100-120). Brill Sense. https://doi.org/10.1163/9789004461529_006

Buabeng-Andoh, C. (2021). Exploring University students' intention to use mobile learning: A research model approach. Education and Information Technologies, 26(1), 241-256. https://doi.org/10.1007/s10639-020-10267-4

Buchs, C., Dumesnil, A., Chanal, J., \& Butera, F. (2021). Dual effects of partner's competence: Resource interdependence in cooperative learning at elementary school. Education Sciences, 11(5), 210. https://doi.org/10.3390/educsci11050210

Budiyanto, T. S. W., Badawi, M. A. H., Kisno, A. K. U., Ade Gunawan, A. M., \& Imam Ali Bashori, A. P. (2021). The Effect of Service Quality on Satisfaction and Loyalty of Paud Student Parents. Psychology and Education, Psychology and Education, 58(1), 2294-2304.

Budur, T., \& Poturak, M. (2021). Transformational leadership and its impact on customer satisfaction. Measuring mediating effects of organisational citizenship behaviours. Middle East Journal of Management, 8(1), 67-91. https://doi.org/10.1504/MEJM.2021.10033657 
Cage, E., \& Howes, J. (2020). Dropping out and moving on: A qualitative study of autistic people's experiences of university. Autism, 24(7), 1664-1675. https://doi.org/10.1177/1362361320918750

Calhoun, K., Hudley, A. H. C., Bucholtz, M., Exford, J., \& Johnson, B. (2021). Attracting Black students to linguistics through a Black-centered Introduction to Linguistics course. Language, 97(1), e12-e38. https://doi.org/10.1353/lan.2021.0007

Camilleri, M. A. (2021). Evaluating service quality and performance of higher education institutions: A systematic review and a post-COVID-19 outlook. International Journal of Quality and Service Sciences, 13(2). https://doi.org/10.1108/IJQSS-03-2020-0034

Carlisle, S., Ivanov, S., \& Dijkmans, C. (2021). The digital skills divide: Evidence from the European tourism industry. Journal of Tourism Futures. https://doi.org/10.1108/JTF-07-2020-0114

Chen, L. H., Wang, M. J. S., \& Morrison, A. M. (2021). Extending the memorable tourism experience model: A study of coffee tourism in Vietnam. British Food Journal, 123(6). https://doi.org/10.1108/BFJ-08-2020-0748

Christian, I. O., Anning-Dorson, T., \& Tackie, N. N. (2021). Customer loyalty and value anticipation: Does perceived competition matter? African Journal of Economic and Management Studies, 12(2). https://doi.org/10.1108/AJEMS-09-2020-0443

Classens, M., Hardman, E., Henderson, N., Sytsma, E., \& Vsetula-Sheffield, A. (2021). Critical food systems education, neoliberalism, and the alternative campus tour. Agroecology and Sustainable Food Systems, 45(3), 450-471. https://doi.org/10.1080/21683565.2020.1829776

Cox, J. (2021). The higher education environment driving academic library strategy: A political, economic, social and technological (PEST) analysis. The Journal of Academic Librarianship, 47(1), 102219. https://doi.org/10.1016/j.acalib.2020.102219

Cus, M., Humes, T., Flowers, A., \& Muschamp, A. (n.d.). Analyzing Students' Perspective of the Learning Management System Moodle at the University of Belize.

Davids, N. (2021). Academic freedom and the fallacy of a post-truth era. Educational Philosophy and Theory, 53(11), 1183-1193. https://doi.org/10.1080/00131857.2021.1917363

Decuypere, M., \& Landri, P. (2021). Governing by visual shapes: university rankings, digital education platforms and cosmologies of higher education. Critical Studies in Education, 62(1), 17-33. https://doi.org/10.1080/17508487.2020.1720760

Diaz, A., Arden, M., Blaustein, S., Nucci-Sack, A., Sanders, L., \& Steever, J. (2021). Using School-Based Health Programs to Prevent Human Trafficking: The Mount Sinai Experience. Annals of Global Health, 87(1). https://doi.org/10.5334/aogh.3049

Dixon, M., Lee, C., \& Corrigan, C. (2021). 'We were all looking at them quite critically': Collaborative reflection on a university-based coach education program. Reflective Practice, 1-16. https://doi.org/10.1080/14623943.2021.1873759

Durnen, A. K. (2021). Principal Leadership Practices in Addressing Teacher Recruitment and Retention in Rural Schools. Doctoral dissertation, Winona State University.

Eberle, J., \& Hobrecht, J. (2021). The lonely struggle with autonomy: A case study of first-year university students' experiences during emergency online teaching. Computers in Human Behavior, 121, 106804. https://doi.org/10.1016/j.chb.2021.106804

Ewing, L. A. (2021). Rethinking higher education post COVID-19. The Future of Service Post-COVID-19 Pandemic, 1, 37. https://doi.org/10.1007/978-981-33-4126-5_3

Fitzpatrick, K. (2021). Generous thinking: A radical approach to saving the university. Johns Hopkins University Press.

Fook, A. C. W., \& Dastane, O. (2021). Effectiveness of Loyalty Programs in Customer Retention: A Multiple Mediation Analysis. Jindal Journal of Business Research, 10(1), 7-32. https://doi.org/10.1177/22786821211000182

Fraser, S., \& Mancl, D. (2021). Exploring the Dimensions of University-Company Collaborations: Research, Talent, and Beyond. In Proc. 8th Intl. Workshop on Software Engineering Research and Industrial Practice (SER\&IP 2021), Madrid. https://doi.org/10.1109/SER-IP52554.2021.00017 
Gbadegesin, J. T., Komolafe, M. O., Gbadegesin, T. F., \& Omotoso, K. O. (2021). Off-campus student housing satisfaction indicators and the drivers: From student perspectives to policy re-awakening in governance. Journal of Human Behavior in the Social Environment, 37(1), 889-915. https://doi.org/10.1080/10911359.2020.1825247

Gupta, A. (2021). Business statistics. RAJEEV BANSAL.

Gupta, R. (2021). The Role of Pedagogy in Developing Life Skills. Margin: The Journal of Applied Economic Research, 15(1), 50-72. https://doi.org/10.1177/0973801020974786

Gyamera, G. O., \& Debrah, I. (2021). Utilising university community engagement as a critical tool for global citizenship. Compare: A Journal of Comparative and International Education, 1-19. https://doi.org/10.1080/03057925.2021.1929074

Haigler, K. (2021). The role of occupational research in complex assessments: Aligning educational practices with workplace requirements. The Journal of Writing Analytics, 5. https://doi.org/10.37514/JWA-J.2021.5.1.08

Hall, J., Gaved, M., \& Sargent, J. (2021). Participatory research approaches in times of Covid-19: A narrative literature review. International Journal of Qualitative Methods, 20, https://doi.org/10.1177/16094069211010087

Hilda, E. O., \& Audu, Y. P. (2021). Customer Relationship Management Practices and Customer Satisfaction in Deposit Money Banks (DMBs) of Kogi State-The Covid-19 Era. International Journal of Public Administration and Management Research, 6(4), 66-79.

Hopkins, K. M. (2021). Developing a Measure of Need to Matter. Doctoral dissertation, North Dakota State University.

Javed, S., Rashidin, M. S., \& Jian, W. (2021). Predictors and outcome of customer satisfaction: Moderating effect of social trust and corporate social responsibility. Future Business Journal, 7(1), 1-18. https://doi.org/10.1186/s43093-021-00055-y

Kazemian, S., \& Grant, S. B. (2021). Antecedents and outcomes of enterprise social network usage within UK higher education. VINE Journal of Information and Knowledge Management Systems. https://doi.org/10.1108/VJIKMS-12-2020-0222

Kenfack, M. R. K., \& Öztüren, A. (2021). Key Factors in the Selection of an Educational Tourism Destination. In Global Perspectives on Recruiting International Students: Challenges and Opportunities. Emerald Publishing Limited. https://doi.org/10.1108/978-1-83982-518-720211001

Khan, K., Hameed, I., \& Hussainy, S. K. (2021). Antecedents and consequences of brand citizenship behavior in private higher education institutions. Journal of Marketing for Higher Education, 1-22. https://doi.org/10.1080/08841241.2021.1927934

Kirimi, D. G. (2021). Influence of Entrepreneurial Networks on Financial Performance of Medium Sized Enterprises in Kenya. Doctoral dissertation, JKUAT-COHRED.

Kryscynski, D., Coff, R., \& Campbell, B. (2021). Charting a path between firm - specific incentives and human capital - based competitive advantage. Strategic Management Journal, 42(2), 386-412. https://doi.org/10.1002/smj.3226

Kuranchie, A., Okyere, M., \& Larbi, E. (2021). A Non-state University's Contribution to the Tertiary Education Landscape in Ghana. International Journal of Academic Research in Progressive Education and Development, 99-113. https://doi.org/10.6007/IJARPED/v10-i1/8327

Kwegyiriba, A., \& Mensah, R. O. (2021). Free Senior High School Policy: Implications to Education Access Equity in Ghana.

Laplume, A., Harrison, J., Zhang, Z., Yu, X., \& Walker, K. (2021). Evidence of an Inverted U-Shaped Relationship Between Stakeholder Management Performance Variation and Firm Performance. Business Ethics Quarterly. https://doi.org/10.1017/beq.2021.19

Lee, Y., Jeong, S., \& Cho, D. (2021). Assessing adult and continuing education needs in South Korea metropolitan areas using Borich's needs assessment model. European Journal of Training and Development. https://doi.org/10.1108/EJTD-08-2020-0133

Li, J., Li, Y., Song, H., \& Fan, C. (2021). Sustainable value creation from a capability perspective: How to 
achieve sustainable product design. Journal of Cleaner Production, 310, 127552. https://doi.org/10.1016/j.jclepro.2021.127552

Liu, C. (2021). Why do firms fail to engage diversity? A behavioral strategy perspective. Organization Science, 32(5). https://doi.org/10.1287/orsc.2020.1425

Marques, C., da Silva, R. V., \& Antova, S. (2021). Image, satisfaction, destination and product post-visit behaviours: How do they relate in emerging destinations? Tourism Management, 85, 104293. https://doi.org/10.1016/j.tourman.2021.104293

Naudé, W., \& Nagler, P. (2021). The Rise and Fall of German Innovation.

Ndichu, E. G., \& Rittenburg, T. L. (2021). Consumers' navigation of risk perceptions in the adoption of stigmatized products. Journal of Business Research, 132, 340-353. https://doi.org/10.1016/j.jbusres.2021.03.057

Nisar, Q. A., Haider, S., Ali, F., Jamshed, S., Ryu, K., \& Gill, S. S. (2021). Green human resource management practices and environmental performance in Malaysian green hotels: The role of green intellectual capital and pro-environmental behavior. Journal of Cleaner Production, 311, 127504. https://doi.org/10.1016/j.jclepro.2021.127504

Nurmukhanova, G., Alibekova, G., Tamenova, S., \& Niyetalina, G. (2021). Strategic Management of Universities for Regional Competitiveness. The Journal of Asian Finance, Economics, and Business, 8(1), 551-562.

Nyakurerwa, A. T. (2021). Quality Assurance and Marketing of Library Services and Products: The Case of Midlands State University. Examining the Impact of Industry, 4, 165-188. https://doi.org/10.1108/978-1-80043-656-520201021

Otto, J. M., Zarrin, M., Wilhelm, D., \& Brunner, J. O. (2021). Analyzing the relative efficiency of internationalization in the university business model: The case of Germany. Studies in Higher Education, 1-13. https://doi.org/10.1080/03075079.2021.1896801

Pflüger, J., \& Mojescik, K. (2021). Governance of academic teaching: why universities introduce funding programs for teaching and why academic teachers participate. Teaching in Higher Education, 1-18. https://doi.org/10.1080/13562517.2021.1900813

Raciti, M. M. (2021). Social marketing hackers. Journal of Social Marketing, 11(3). https://doi.org/10.1108/JSOCM-12-2020-0238

Rotberg, R. (2020). Things come together: Africans achieving greatness in the twenty-first century. Oxford University Press, USA. https://doi.org/10.1093/oso/9780190942540.001.0001

Scharoun, L., \& Muratovski, G. (2021). Leading a Design School: Practices from Australia and the USA. In How to Be a Design Academic (pp. 307-326). CRC Press. https://doi.org/10.1201/9780429351693-25

Shahzad, A., Hassan, R., Aremu, A. Y., Hussain, A., \& Lodhi, R. N. (2021). Effects of COVID-19 in E-learning on higher education institution students: the group comparison between male and female. Quality \& Quantity, 55(3), 805-826. https://doi.org/10.1007/s11135-020-01028-z

Shaikh, Z. M. (2020). A critical comparative study on the national accreditation standards for hospitals of India, Australia, Denmark and South Africa (vol. 1). Ky publications.

Shuh, J. J. (2021). An Examination of Institutional Structures, Policy, Narratives and Professorial and Other Stakeholder Perceptions and Experiences vis-à-vis Academic Integrity. Doctoral dissertation, University of Toronto (Canada).

Smart, C. A. (2021). Towards transformative enagagement: The international and foreign student stakeholder in the academic library; a view from the subaltern. Doctoral dissertation, Queensland University of Technology.

Steimer, L. (2021). Experts in Action: Transnational Hong Kong-Style Stunt Work and Performance. Duke University Press. https://doi.org/10.1215/9781478021261

Suleiman, Y., Ishola, M. A., Abubakar, L., \& Aliyu, L. A. (n.d.). Adequate funding: A tool for quality assurance in Nigerian tertiary institutions.

Swift, R. (2021). Qualitatively Different Ways of Experiencing Higher Education Teaching Excellence: A Phenomenographic Enquiry into the Conceptions of Teaching Practitioners of Their Experiences of Higher Education Teaching Excellence Within College-Based Higher Education. Doctoral dissertation, Lancaster 
University (United Kingdom).

Tariq, J., Khan, K., Hussainy, S. K., \& Tariq, S (2021). Antecedents and Consequences of Student Loyalty in Higher Education. JISR MSSE Journal Contents, 18(2). https://doi.org/10.31384/jisrmsse/2020.18.2.3

Tight, M. (2021). Globalization and internationalization as frameworks for higher education research. Research Papers in Education, 36(1), 52-74. https://doi.org/10.1080/02671522.2019.1633560

Tu, Y., \& Wu, W. (2021). How does green innovation improve enterprises' competitive advantage? The role of organizational learning. Sustainable Production and Consumption, 26, 504-516. https://doi.org/10.1016/j.spc.2020.12.031

Uriegas, N. A., Emerson, D. M., Smith, A. B., Kelly, M. R., \& Torres-McGehee, T. M. (2021). Examination of eating disorder risk among university marching band artists. Journal of Eating Disorders, 9(1), 1-10. https://doi.org/10.1186/s40337-021-00388-7

Vargas-Hernández, J. G., \& Ibarra, S. T. C. (2021). Evaluating Higher Education Institutions through Agency and Resource-Capabilities Theories: A Model for Measuring the Perceived Quality of Service. In Research Anthology on Preparing School Administrators to Lead Quality Education Programs (pp. 353-375). IGI Global. https://doi.org/10.4018/978-1-7998-3438-0.ch017

Yapanto, L., Diah, A., Kankaew, K., Dewi, A., Dextre-Martinez, W., Kurniullah, A., \& Villanueva-Benites, L. (2021). The effect of CRM on employee performance in banking industry. Uncertain Supply Chain Management, 9(2), 295-306. https://doi.org/10.5267/j.uscm.2021.3.003

Zahia, K., Moskal, M., \& Read, B. (2021). Compelled to Compete: Chinese graduates on employment and social mobility after international and domestic study. International Journal of Educational Development, 84, 102432. https://doi.org/10.1016/j.ijedudev.2021.102432

Zina, O. (2021). The essential guide to doing your research project. Sage.

\section{Copyrights}

Copyright for this article is retained by the author, with first publication rights granted to the journal.

This is an open-access article distributed under the terms and conditions of the Creative Commons Attribution license (http://creativecommons.org/licenses/by/4.0/). 